\title{
Evidence-Based PET for Abdominal and Pelvic Tumours
}

\author{
Salvatore Annunziata, Daniele Antonio Pizzuto, \\ and Federica Galiandro
}

\subsection{Introduction}

Evidence-based data about the usefulness of positron emission tomography (PET) and hybrid imaging methods (PET/CT and PET/MRI) in abdominal and pelvic tumours have been collected and discussed in this chapter. These data were divided in three sections: (1) gastrointestinal tumours, (2) uro-genital tumours, (3) gynaecological tumours. Several pooled data (diagnostic and prognostic data), clinical settings (e.g. staging, restaging, treatment evaluation) and radiotracers as fluorine-18 fluorodeoxyglucose $\left({ }^{18} \mathrm{~F}-\mathrm{FDG}\right)$, radiolabelled choline and prostatespecific membrane antigen (PSMA) were considered.

S. Annunziata $(\bowtie)$

Nuclear Medicine Unit, IRCCS Regina Elena

National Cancer Institute, Rome, Italy

D. A. Pizzuto

Department of Nuclear Medicine, University Hospital

Zurich and University of Zurich, Zurich, Switzerland

F. Galiandro

Department of Digestive Surgery, Fondazione Policlinico Universitario Agostino Gemelli IRCCS,

Rome, Italy

\subsection{PET in Gastrointestinal Tumours}

Fifty-two meta-analyses on the role of PET imaging in gastrointestinal tumours have been selected [1-52]. Pooled data about PET/CT in colorectal cancer, gastric cancer, anal cancer, stromal tumours, hepato-biliary tumours, liver metastases and pancreatic cancer have been reported in Table 7.1.

\subsubsection{Colorectal Cancer}

Fourteen meta-analyses about ${ }^{18} \mathrm{~F}$-FDG PET/CT in colorectal cancer have been found [1-14]. Two meta-analyses evaluated the role of this imaging method in a staging setting, showing good specificity but low sensitivity [4, 13]. Similarly, two studies showed high accuracy in a restaging setting [7, 12]. Some meta-analyses assessed sub-optimal accuracy in treatment evaluation [3, 6, 8, 10, 14]. Recent meta-analyses found that focal colorectal incidental uptake at ${ }^{18} \mathrm{~F}$-FDG PET/CT is observed in a not negligible number of patients who undergo this imaging method with a high risk of malignant or premalignant lesions $[2,9]$. Finally, poor predictive or prognostic role of ${ }^{18} \mathrm{~F}$-FDG PET/CT in colorectal cancer emerged [1, 5, 11]. 
Table 7.1 Main findings of meta-analyses about the role of PET imaging in gastrointestinal tumours

\begin{tabular}{|c|c|c|c|c|c|c|}
\hline Tumours & Authors & Topic & $\begin{array}{l}\text { Pooled } \\
\text { sensitivity }\end{array}$ & $\begin{array}{l}\text { Pooled } \\
\text { specificity }\end{array}$ & PFS HR & OS HR \\
\hline \multirow[t]{14}{*}{ Colorectal cancer } & Kim et al. [1] & Prediction & 0.66 & 0.67 & - & - \\
\hline & Son et al. [2] & Characterization & 0.87 & 0.83 & - & - \\
\hline & Rymer et al. [3] & $\begin{array}{l}\text { Treatment } \\
\text { evaluation }\end{array}$ & - & - & - & - \\
\hline & Ye et al. [4] & $\mathrm{T}$ staging & 0.73 & 0.99 & - & - \\
\hline & Xia et al. [5] & Prognosis & - & - & 0.45 & 0.36 \\
\hline & Maffione et al. [6] & $\begin{array}{l}\text { Treatment } \\
\text { evaluation }\end{array}$ & 0.73 & 0.77 & - & - \\
\hline & Yu et al. [7] & Restaging & 0.94 & 0.94 & - & - \\
\hline & Li et al. [8] & $\begin{array}{l}\text { Treatment } \\
\text { evaluation }\end{array}$ & 0.81 & - & - & - \\
\hline & Treglia et al. [9] & Characterization & - & - & - & - \\
\hline & Li et al. [10] & $\begin{array}{l}\text { Treatment } \\
\text { evaluation }\end{array}$ & 0.78 & 0.81 & - & - \\
\hline & Krug et al. [11] & Prognosis & - & - & 0.70 & 0.39 \\
\hline & Lu et al. [12] & Restaging & 0.90 & 0.80 & - & - \\
\hline & Lu et al. [13] & $\mathrm{N}$ staging & 0.43 & 0.88 & - & - \\
\hline & Zhang et al. [14] & $\begin{array}{l}\text { Treatment } \\
\text { evaluation }\end{array}$ & 0.78 & 0.66 & - & - \\
\hline \multirow[t]{7}{*}{ Gastric cancer } & Luo et al. [15] & $\mathrm{N}$ staging & 0.52 & 0.88 & - & - \\
\hline & Wu et al. [16] & Prognosis & - & - & 1.70 & 1.72 \\
\hline & Li et al. [17] & Restaging & 0.85 & 0.78 & - & - \\
\hline & Zou et al. [18] & Restaging & 0.86 & 0.88 & - & - \\
\hline & Cui et al. [19] & Staging & 0.92 & 0.89 & - & - \\
\hline & Wu et al. [20] & Restaging & 0.78 & 0.82 & - & - \\
\hline & $\begin{array}{l}\text { Seevaratnam et al. } \\
\text { [21] }\end{array}$ & $\mathrm{N}$ staging & 0.40 & 0.98 & - & - \\
\hline \multirow[t]{5}{*}{ Anal cancer } & Sadeghi et al. [22] & Prognosis & - & - & 5.36 & 5.87 \\
\hline & $\begin{array}{l}\text { Albertsson et al. } \\
\text { [23] }\end{array}$ & RT planning & - & - & - & - \\
\hline & Mahmud et al. [24] & $\mathrm{N}$ staging & 0.93 & 0.76 & - & - \\
\hline & Jones et al. [25] & Staging & 0.99 & - & - & - \\
\hline & $\begin{array}{l}\text { Caldarella et al. } \\
\text { [26] }\end{array}$ & $\mathrm{N}$ staging & 0.56 & 0.90 & - & - \\
\hline \multirow{2}{*}{$\begin{array}{l}\text { Stromal tumours } \\
\text { (GIST) }\end{array}$} & Kim et al. [27] & Predictive value & 0.88 & 0.88 & - & - \\
\hline & $\begin{array}{l}\text { Hassanzadeh et al. } \\
\text { [28] }\end{array}$ & $\begin{array}{l}\text { Treatment } \\
\text { evaluation }\end{array}$ & 0.90 & 0.62 & - & - \\
\hline \multirow{9}{*}{$\begin{array}{l}\text { Hepato-biliary } \\
\text { tumours }\end{array}$} & Liao et al. [29] & Restaging & 0.64 & 0.95 & - & - \\
\hline & Hu et al. [30] & Staging & 0.80 & 0.70 & - & - \\
\hline & Sun et al. [31] & Prognosis & - & - & 7.2 & 2.1 \\
\hline & $\begin{array}{l}\text { Annunziata et al. } \\
\text { [32] }\end{array}$ & Staging & 0.87 & 0.78 & - & - \\
\hline & Zhang et al. [33] & Staging & 0.91 & 0.81 & - & - \\
\hline & Bertagna et al. [34] & Staging & - & - & - & - \\
\hline & Chou et al. [35] & M staging & 0.82 & - & - & - \\
\hline & $\begin{array}{l}\text { Annunziata et al. } \\
\text { [36] }\end{array}$ & Staging & 0.81 & 0.82 & - & - \\
\hline & Lin et al. [37] & M staging & 0.77 & 0.98 & - & - \\
\hline
\end{tabular}


Table 7.1 (continued)

\begin{tabular}{|c|c|c|c|c|c|c|}
\hline Tumours & Authors & Topic & $\begin{array}{l}\text { Pooled } \\
\text { sensitivity }\end{array}$ & $\begin{array}{l}\text { Pooled } \\
\text { specificity }\end{array}$ & PFS HR & OS HR \\
\hline \multirow[t]{7}{*}{ Liver metastases } & Choi et al. [38] & Staging & 0.74 & 0.94 & - & - \\
\hline & Samim et al. [39] & $\begin{array}{l}\text { Treatment } \\
\text { evaluation }\end{array}$ & 0.84 & 0.92 & - & - \\
\hline & Maffione et al. [40] & Staging & 0.93 & 0.93 & - & - \\
\hline & Deng et al. [41] & Staging & 0.84 & 0.99 & - & - \\
\hline & Zheng et al. [42] & $\begin{array}{l}\text { Treatment } \\
\text { evaluation }\end{array}$ & 0.79 & 0.84 & - & - \\
\hline & Poulu et al. [43] & Restaging & 0.73 & 0.85 & - & - \\
\hline & $\begin{array}{l}\text { van Kessel et al. } \\
{[44]}\end{array}$ & $\begin{array}{l}\text { Treatment } \\
\text { evaluation }\end{array}$ & 0.54 & $\mathrm{n} / \mathrm{a}$ & - & - \\
\hline \multirow[t]{8}{*}{ Pancreatic cancer } & Daamen et al. [45] & Restaging & 0.88 & 0.89 & - & - \\
\hline & Wang et al. [46] & M staging & - & - & - & - \\
\hline & Zhu et al. [47] & Prognosis & - & - & 1.90 & 1.70 \\
\hline & Toft et al. [48] & Staging & 0.89 & 0.70 & - & - \\
\hline & Best et al. [49] & Characterization & 0.92 & 0.65 & - & - \\
\hline & Rijkers et al. [50] & Characterization & 0.90 & 0.76 & - & - \\
\hline & Wang et al. [51] & Staging/prognosis & 0.91 & 0.81 & - & 2.39 \\
\hline & Wu et al. [52] & Staging & 0.87 & 0.83 & - & - \\
\hline
\end{tabular}

$H R$ hazard ratio, $P F S$ progression free survival, $O S$ overall survival

\subsubsection{Gastric Cancer}

Seven meta-analyses analysed the role of ${ }^{18} \mathrm{~F}-$ FDG PET/CT in gastric cancer [15-21]. Three meta-analyses found a good accuracy in a staging setting, but with low sensitivity in detecting lymph nodal $(\mathrm{N})$ involvement $[15,19,21]$. Conversely, other meta-analyses showed a good accuracy in a restaging setting $[17,18,20]$. Only one evidence-based article demonstrated a suboptimal prognostic value of ${ }^{18} \mathrm{~F}-\mathrm{FDG} \mathrm{PET} / \mathrm{CT}$ in gastric cancer [16].

\subsubsection{Anal Cancer}

Five meta-analyses about ${ }^{18} \mathrm{~F}$-FDG PET/CT in anal cancer have been included [22-26]. Some meta-analyses evaluated the role in a staging setting, with discordant accuracy values [24-26]. One meta-analysis found a strong prognostic power of ${ }^{18} \mathrm{~F}$-FDG PET parameters for progression free survival (PFS) and overall survival (OS) [22]. Finally, another meta-analysis assessed the role of ${ }^{18} \mathrm{~F}-\mathrm{FDG}$ PET/CT in radiotherapy planning [23].

\subsubsection{Stromal Tumours (GIST)}

Two meta-analyses about the role of ${ }^{18} \mathrm{~F}-\mathrm{FDG}$ $\mathrm{PET} / \mathrm{CT}$ in treatment evaluation and prediction of malignant potential in patients with GIST have been found and included [27, 28], suggesting a role of this imaging method in these settings.

\subsubsection{Hepato-biliary Tumours}

Nine meta-analyses about ${ }^{18} \mathrm{~F}$-FDG PET/CT in hepatic and biliary tumours have been included [29-37]. Some meta-analyses found a role of ${ }^{18} \mathrm{~F}$ FDG PET/CT in a staging setting, in particular about detection of distant metastases (M) [30, 32, $33,35-37]$. One meta-analysis found low sensitivity in a restaging setting [29]. Conversely, another meta-analysis showed high prognostic power for PFS by ${ }^{18} \mathrm{~F}$-FDG PET/CT in hepatobiliary tumours [31]. Beyond ${ }^{18} \mathrm{~F}-\mathrm{FDG}$, radiolabelled choline PET/CT showed a good detection rate of tumour lesions in patients with hepatocellular carcinoma [34]. 


\subsubsection{Liver Metastases}

Seven meta-analyses about the role of ${ }^{18} \mathrm{~F}-\mathrm{FDG}$ $\mathrm{PET} / \mathrm{CT}$ in detecting liver metastases from different primary tumours have been found [38-44]. Some studies showed high specificity in a staging setting [38, 40, 41]. One study found a suboptimal sensitivity also in a restaging setting [43]. The role in treatment evaluation improved in a recent meta-analysis $[42,44]$.

\subsubsection{Pancreatic Cancer}

Eight meta-analyses about ${ }^{18} \mathrm{~F}-\mathrm{FDG}$ PET/CT in pancreatic cancer have been published and included [45-52]. Interestingly, some papers showed good sensitivity in a staging setting [46, $48,51,52]$. Two studies demonstrated a good accuracy of this imaging method in characterizing pancreatic lesions [49, 50]. Finally, two meta-analyses found a prognostic power for ${ }^{18} \mathrm{~F}$ FDG PET/CT in pancreatic cancer $[47,51]$.

\subsection{PET in Gynaecological Tumours}

Thirty-three meta-analyses on the role of ${ }^{18} \mathrm{~F}$ FDG PET imaging in gynaecological tumours have been selected [53-82]. Pooled data about ${ }^{18} \mathrm{~F}-\mathrm{FDG} \mathrm{PET} / \mathrm{CT}$ in cervical cancer, endometrial cancer, ovarian cancer and peritoneal carcinomatosis have been reported in Table 7.2.

\subsubsection{Cervical Cancer}

Twelve meta-analyses about the role of ${ }^{18} \mathrm{~F}-\mathrm{FDG}$ $\mathrm{PET} / \mathrm{CT}$ in cervical cancer have been included [53-64]. Some studies evaluated the role of ${ }^{18} \mathrm{~F}$ FDG PET/CT in staging cervical cancer, showing low sensitivity and high specificity in $\mathrm{N}$ staging $[53,56,64]$. Several studies evaluated the role of ${ }^{18} \mathrm{~F}$-FDG PET/CT in a restaging setting, with high values of sensitivity and specificity $[55,58-$
$61,63]$. Some meta-analyses found a prognostic role of ${ }^{18} \mathrm{~F}-\mathrm{FDG}$ PET/CT in cervical cancer [54, $57,62]$.

\subsubsection{Endometrial Cancer}

Seven meta-analyses about the role of ${ }^{18} \mathrm{~F}-\mathrm{FDG}$ $\mathrm{PET} / \mathrm{CT}$ in endometrial cancer have been included [65-71]. Some meta-analyses evaluated the role of ${ }^{18} \mathrm{~F}-\mathrm{FDG}$ PET/CT in a staging or restaging setting, showing good values of sensitivity and specificity [65, 68-71]. Conversely, one meta-analysis showed low sensitivity in $\mathrm{N}$ staging [71]. Finally, some meta-analyses showed a prognostic role of ${ }^{18} \mathrm{~F}-\mathrm{FDG}$ PET/CT for PFS $[66,67]$.

\subsubsection{Ovarian Cancer}

Six meta-analyses about ${ }^{18} \mathrm{~F}-\mathrm{FDG}$ PET/CT in ovarian cancer have been found [72-77]. Some meta-analyses showed high accuracy of this imaging method in a restaging setting [74-76]. Conversely, some meta-analyses showed sub-optimal sensitivity in $\mathrm{N}$ and $\mathrm{M}$ staging [72, 77]. Only one meta-analysis showed a good prognostic power of ${ }^{18} \mathrm{~F}$-FDG PET/CT in ovarian cancer, with particular regard to OS [73].

\subsubsection{Peritoneal Carcinomatosis}

Three meta-analyses were focused on the role of ${ }^{18} \mathrm{~F}-\mathrm{FDG}$ PET/CT in peritoneal carcinomatosis, showing good values of sensitivity and specificity of this method in this setting [78-80].

\subsubsection{PET/MRI}

Finally, recent studies evaluated the role of ${ }^{18} \mathrm{~F}$ FDG PET/MRI in gynaecological malignancies, showing optimal diagnostic accuracy values $[81,82]$. 
Table 7.2 Main findings of meta-analyses about the role of PET imaging in gynaecological tumours

\begin{tabular}{|c|c|c|c|c|c|c|}
\hline Tumours & Authors & Topic & $\begin{array}{l}\text { Pooled } \\
\text { sensitivity }\end{array}$ & $\begin{array}{l}\text { Pooled } \\
\text { specificity }\end{array}$ & PFS HR & OS HR \\
\hline \multirow[t]{12}{*}{ Cervical cancer } & Ruan [53] & $\mathrm{N}$ staging & 0.72 & 0.96 & - & - \\
\hline & Han [54] & Prognosis & - & - & 5.89 & 6.62 \\
\hline & Zhou [55] & Restaging & 0.97 & 0.81 & - & - \\
\hline & Liu [56] & $\mathrm{N}$ staging & 0.66 & 0.96 & - & - \\
\hline & Sarker [57] & Prognosis & - & - & 2.66 & 2.45 \\
\hline & Xiao [58] & Restaging & 0.94 & 0.92 & - & - \\
\hline & Ding [59] & Restaging & 0.92 & 0.94 & - & - \\
\hline & Meads [60] & Restaging & 0.95 & 0.87 & - & - \\
\hline & Chu [61] & Restaging & 0.87 & 0.97 & - & - \\
\hline & Zhao [62] & Prognosis & - & - & - & 2.06 \\
\hline & Meads [63] & Restaging & 0.92 & 0.88 & - & - \\
\hline & Gong [64] & $\mathrm{N}$ staging & 0.68 & 0.97 & - & - \\
\hline \multirow[t]{7}{*}{ Endometrial cancer } & Bollineni [65] & Restaging & 0.95 & 0.91 & - & - \\
\hline & Pan [66] & Prognosis & - & - & 3.33 & 1.31 \\
\hline & $\begin{array}{l}\text { Ghooshkhanei } \\
{[67]}\end{array}$ & Prognosis & - & - & 7.4 & - \\
\hline & Kakhki [68] & Staging & 0.82 & 0.90 & - & - \\
\hline & Sadeghi [69] & Restaging & 0.92 & 0.96 & - & - \\
\hline & $\begin{array}{l}\text { Kadkhodayan } \\
{[70]}\end{array}$ & Restaging & 0.96 & 0.92 & - & - \\
\hline & Chang [71] & $\mathrm{N}$ staging & 0.63 & 0.95 & - & - \\
\hline \multirow[t]{6}{*}{ Ovarian cancer } & Han [72] & M staging & 0.72 & 0.93 & - & - \\
\hline & Han [73] & Prognosis & - & - & 2.50 & 8.06 \\
\hline & Suppiah [74] & Restaging & 0.90 & 0.90 & - & - \\
\hline & $\mathrm{Xu}$ [75] & Restaging & 0.92 & 0.91 & - & - \\
\hline & Limei [76] & Restaging & 0.87 & 0.90 & - & - \\
\hline & Yuan [77] & $\mathrm{N}$ staging & 0.73 & 0.97 & - & - \\
\hline \multirow[t]{3}{*}{ Peritoneal carcinomatosis } & Kim [78] & Diagnosis & 0.87 & 0.92 & - & - \\
\hline & Li [79] & Diagnosis & 0.84 & 0.98 & - & - \\
\hline & Chang [80] & Diagnosis & 0.72 & 0.97 & - & - \\
\hline \multirow[t]{2}{*}{ PET/MRI } & Zheng [81] & Restaging & 0.96 & 0.95 & - & - \\
\hline & Nie [82] & Staging & 0.95 & 0.95 & - & - \\
\hline
\end{tabular}

$H R$ hazard ratio, $P F S$ progression free survival, $O S$ overall survival

\subsection{PET in Uro-genital Tumours}

Thirty-five meta-analyses on the role of PET imaging in uro-genital tumours have been selected [83-117]. In particular, pooled data about radiolabelled choline, PSMA and fluciclovine $\mathrm{PET} / \mathrm{CT}$ in prostate cancer and ${ }^{18} \mathrm{~F}-\mathrm{FDG}$ PET/CT in bladder cancer, renal cell carcinoma, testicular and penile cancer have been included (Table 7.3).

\subsubsection{Prostate Cancer}

\subsubsection{Radiolabelled Choline PET for Prostate Cancer}

Several meta-analyses described a very high specificity for detection of local lymph node involvement and for detection of distant metastases of prostate cancer by using radiolabelled choline PET. Radiolabelled choline PET is also widely used in patients with suspected biochemi- 
Table 7.3 Main findings of meta-analyses about the role of PET imaging in uro-genital tumours

\begin{tabular}{|c|c|c|c|c|c|}
\hline Tumours & Authors & Tracers & Topic & Sensitivity & Specificity \\
\hline \multirow{23}{*}{$\begin{array}{l}\text { Prostate } \\
\text { cancer }\end{array}$} & Evangelista et al. [83] & Choline & $\mathrm{N}$ staging & 0.49 & 0.95 \\
\hline & Evangelista et al. [85] & Choline & Restaging & 0.85 & - \\
\hline & Evangelista et al. [84] & Choline & Staging & 0.86 & 0.93 \\
\hline & Fanti et al. [86] & Choline & Restaging & 0.89 & 0.89 \\
\hline & Guo et al. [90] & Choline & M staging & 0.89 & 0.98 \\
\hline & Liu et al. [92] & Several tracers & Staging & 0.83 (choline) & 0.93 (choline) \\
\hline & Beheshti et al. [93] & Acetate & Staging & 0.75 & 0.76 \\
\hline & Ouyang et al. [94] & Several tracers & Staging & 0.78 (choline) & 0.90 (choline) \\
\hline & Ren et al. [115] & Fluciclovine & Restaging & 0.87 & 0.66 \\
\hline & $\begin{array}{l}\text { Sathianathen et al. } \\
\text { [116] }\end{array}$ & Several tracers & Restaging & $\begin{array}{l}0.81 \text { (choline) } \\
0.80 \\
\text { (fluciclovine) } \\
0.76 \text { (PSMA) }\end{array}$ & $\begin{array}{l}0.84 \text { (choline) } \\
0.62 \\
\text { (fluciclovine) } \\
0.99 \text { (PSMA) }\end{array}$ \\
\hline & Shen et al. [91] & Choline & M staging & 0.91 & 0.99 \\
\hline & Treglia et al. [88] & Choline & Restaging & - & - \\
\hline & Umbehr et al. [87] & Choline & Staging & 0.84 & 0.79 \\
\hline & Von Eyben et al. [95] & Choline & $M$ restaging & - & - \\
\hline & Wei et al. [89] & Choline & Staging & 0.82 & 0.92 \\
\hline & Bertagna et al. [117] & FDG & Prediction & - & - \\
\hline & Corfield et al. [96] & PSMA & Staging & - & - \\
\hline & Han et al. [98] & PSMA & Management & $\mathrm{n} / \mathrm{a}$ & $\mathrm{n} / \mathrm{a}$ \\
\hline & Kim et al. [99] & PSMA & Staging & 0.71 & 0.95 \\
\hline & Pereira et al. [102] & PSMA & Restaging & - & - \\
\hline & Perera et al. [100] & PSMA & Staging & 0.86 & 0.86 \\
\hline & von Eyben [101] & PSMA & Staging & 0.70 & 0.84 \\
\hline & Hope et al. [97] & PSMA & Restaging & 0.74 & 0.96 \\
\hline \multirow{7}{*}{$\begin{array}{l}\text { Bladder } \\
\text { cancer }\end{array}$} & Lu et al. [105] & FDG & Staging & 0.90 & 1 \\
\hline & Soubra et al. [106] & FDG & Prediction & 0.56 & 0.95 \\
\hline & Wang et al. [107] & FDG & Staging & 0.80 & 0.84 \\
\hline & Zhang et al. [108] & FDG & Staging & 0.82 & 0.92 \\
\hline & Ha et al. [104] & FDG & $\mathrm{N}$ staging & 0.57 & 0.92 \\
\hline & Crozier et al. [103] & FDG & Staging & 0.56 & 0.92 \\
\hline & Kim et al. [109] & Choline and acetate & $\mathrm{N}$ staging & 0.66 & 0.89 \\
\hline \multirow{2}{*}{$\begin{array}{l}\text { Testicular } \\
\text { cancer }\end{array}$} & Zhao et al. [112] & FDG & Staging & 0.75 & 0.87 \\
\hline & Treglia et al. [113] & FDG & $\begin{array}{l}\text { Treatment } \\
\text { evaluation }\end{array}$ & 0.78 & 0.86 \\
\hline \multirow{2}{*}{$\begin{array}{l}\text { Renal cell } \\
\text { carcinoma }\end{array}$} & Wang et al. [111] & FDG & Staging & 0.91 & 0.88 \\
\hline & Ma et al. [110] & FDG & Restaging & 0.86 & 0.88 \\
\hline $\begin{array}{l}\text { Penile } \\
\text { cancer }\end{array}$ & Sadeghi et al. [114] & FDG & $\mathrm{N}$ staging & 0.81 & 0.92 \\
\hline
\end{tabular}

FDG fluorodeoxyglucose, PSMA prostate-specific membrane antigen

cal relapse after initial treatments, even as a guide for salvage lymph node dissection [83-87]. Additionally, PSA kinetics was shown to be strongly related to the detection rate in patients undergoing radiolabelled choline PET [88]. Similarly, high PSA trigger was shown to be an important risk factor for positive findings of radiolabelled choline PET/CT [89]. PET with radiolabelled choline is a well-established imaging tool in clinical practice for detection of bone metastases [90, 91]. Diagnostic accuracy of radiolabelled choline PET was proven to be superior than other radiotracers as ${ }^{18} \mathrm{~F}-\mathrm{FDG}$ and ${ }^{11} \mathrm{C}$-acetate [92], even if ${ }^{11} \mathrm{C}$-acetate PET could be 
considered in patients with relapse [93]. ${ }^{18} \mathrm{~F}$-fluorocholine $(\mathrm{FCH})$ PET showed higher specificity than ${ }^{11} \mathrm{C}$-choline PET [94]. Conversely, the choice of ${ }^{18} \mathrm{~F}-\mathrm{FCH}$ or ${ }^{11} \mathrm{C}$-choline might not affect the detection of metastases in restaging patients after primary surgery and/or radiotherapy [95].

\subsubsection{Radiolabelled PSMA PET in Prostate Cancer}

Radiolabelled PSMA PET showed higher detection rate than other imaging modalities in prostate cancer [96, 97]. It was also proven to alter significantly the clinical management of these patients [98]. Diagnostic performance of PSMA PET was high for detection of node involvement in intermediate- and high-risk prostate cancer patients [99-101]. PSA kinetics may be predictor of radiolabelled PSMA PET positivity in patients with biochemical relapse [102]. PSMA detection rate ranged from $64 \%$ to $97 \%$ when PSA trigger was over $2 \mathrm{ng} / \mathrm{ml}$ at the time of scan [97].

\subsubsection{Fluciclovine PET in Prostate Cancer}

A meta-analysis demonstrated that fluciclovine $\left({ }^{18} \mathrm{~F}-\mathrm{FACBC}\right) \mathrm{PET} / \mathrm{CT}$ had an $87 \%$ pooled sensitivity and $66 \%$ pooled specificity in detecting prostate cancer recurrence, being a useful imaging method in this setting [115].

\subsubsection{Incidental ${ }^{18}$ F-FDG Uptake in the Prostate}

A meta-analysis demonstrated that incidental ${ }^{18} \mathrm{~F}$ FDG uptake in the prostate is observed in about $2 \%$ of ${ }^{18} \mathrm{~F}-\mathrm{FDG} \mathrm{PET} / \mathrm{CT}$ scans performed in male patients carrying a significant risk of malignancy. Therefore, whenever this finding is detected further investigation is warranted to exclude malignancy [117].

\subsubsection{Bladder Cancer}

Several evidence-based articles were focused on the clinical usefulness of ${ }^{18} \mathrm{~F}-\mathrm{FDG}$ PET/CT in patients with bladder cancer [103-109]. An over- all sensitivity and specificity of $82 \%$ and $92 \%$ was reported, respectively [108]. Sensitivity and specificity were $90 \%$ and $100 \%$, respectively, for primary staging, and $82 \%$ and $89 \%$, respectively, for restaging [105]. For detection of node metastases, specificity was found high, whereas sensitivity was poor $[103,104,106]$. Additionally, detection of node involvement was assessed by other radiopharmaceuticals such as ${ }^{11} \mathrm{C}$-choline or ${ }^{11} \mathrm{C}$-acetate [109], showing low sensitivity and moderate specificity.

\subsubsection{Renal Cell Carcinoma}

Values of sensitivity and specificity of ${ }^{18} \mathrm{~F}-\mathrm{FDG}$ $\mathrm{PET} / \mathrm{CT}$ were $86 \%$ and $88 \%$, respectively, for detection of recurrence [110]. If diagnostic performance of ${ }^{18} \mathrm{~F}$-FDG PET/CT for detection of recurrent renal and extra-renal lesions was assessed separately, sensitivity and specificity of extra-renal lesions was found superior than accuracy for renal lesions [111].

\subsubsection{Testicular and Penile Cancer}

${ }^{18} \mathrm{~F}-\mathrm{FDG}$-PET sensitivity was non-optimal in the evaluation of patients with testicular cancer [112]. Similar results were drawn if PET was performed after chemotherapy treatment in patients with seminoma [113]. Clinical usefulness of ${ }^{18} \mathrm{~F}-$ FDG PET for detection of metastatic inguinal lymph nodes in patients with penile cancer is controversial [114].

\section{References}

1. Kim SJ, Pak K, Kim K. Diagnostic performance of F-18 FDG PET/CT for prediction of KRAS mutation in colorectal cancer patients: a systematic review and meta-analysis. Abdom Radiol. 2019;44(5):1703-11.

2. Son GM, Kim SJ. Diagnostic accuracy of F-18 FDG PET/CT for characterization of colorectal focal FDG uptake: a systematic review and meta-analysis. Abdom Radiol. 2019;44(2):456-63.

3. Rymer B, Curtis NJ, Siddiqui MR, Chand M. FDG $\mathrm{PET} / \mathrm{CT}$ can assess the response of locally advanced 
rectal cancer to neoadjuvant chemoradiotherapy: evidence from meta-analysis and systematic review. Clin Nucl Med. 2016;41(5):371-5.

4. Ye Y, Liu T, Lu L, Wang G, Wang M, Li J, et al. Pre-operative TNM staging of primary colorectal cancer by (18)F-FDG PET-CT or PET: a metaanalysis including 2283 patients. Int J Clin Exp Med. 2015;8(11):21773-85.

5. Xia Q, Liu J, Wu C, Song S, Tong L, Huang G, et al. Prognostic significance of (18)FDG PET/CT in colorectal cancer patients with liver metastases: a meta-analysis. Cancer Imaging. 2015;15:19.

6. Maffione AM, Marzola MC, Capirci C, Colletti PM, Rubello D. Value of (18)F-FDG PET for predicting response to neoadjuvant therapy in rectal cancer: systematic review and meta-analysis. AJR Am J Roentgenol. 2015;204(6):1261-8.

7. Yu T, Meng N, Chi D, Zhao Y, Wang K, Luo Y. Diagnostic value of (18)F-FDG PET/CT in detecting local recurrent colorectal cancer: a pooled analysis of 26 individual studies. Cell Biochem Biophys. 2015 Jun;72(2):443-51.

8. Li YL, Wu LM, Chen XX, Delproposto Z, Hu JN, $\mathrm{Xu}$ JR. Is diffusion-weighted MRI superior to FDGPET or FDG-PET/CT in evaluating and predicting pathological response to preoperative neoadjuvant therapy in patients with rectal cancer? J Dig Dis. 2014;15(10):525-37.

9. Treglia G, Taralli S, Salsano M, Muoio B, Sadeghi $\mathrm{R}$, Giovanella L. Prevalence and malignancy risk of focal colorectal incidental uptake detected by (18) F-FDG-PET or PET/CT: a meta-analysis. Radiol Oncol. 2014;48(2):99-104.

10. Li C, Lan X, Yuan H, Feng H, Xia X, Zhang Y. 18FFDG PET predicts pathological response to preoperative chemoradiotherapy in patients with primary rectal cancer: a meta-analysis. Ann Nucl Med. 2014;28(5):436-46.

11. Krug B, Crott R, de Cannière L, D'Hondt L, Vander Borght T. A systematic review of the predictive value of 18F-fluoro-2-deoxyglucose positron emission tomography on survival in locally advanced rectal cancer after neoadjuvant chemoradiation. Color Dis. 2013;15(11):e627-33.

12. Lu YY, Chen JH, Chien CR, Chen WT, Tsai SC, Lin WY, et al. Use of FDG-PET or PET/CT to detect recurrent colorectal cancer in patients with elevated CEA: a systematic review and meta-analysis. Int J Color Dis. 2013;28(8):1039-47.

13. Lu YY, Chen JH, Ding HJ, Chien CR, Lin WY, Kao $\mathrm{CH}$. A systematic review and meta-analysis of pretherapeutic lymph node staging of colorectal cancer by $18 \mathrm{~F}-F D G$ PET or PET/CT. Nucl Med Commun. 2012;33(11):1127-33.

14. Zhang C, Tong J, Sun X, Liu J, Wang Y, Huang G. 18F-FDG-PET evaluation of treatment response to neo-adjuvant therapy in patients with locally advanced rectal cancer: a meta-analysis. Int $\mathrm{J}$ Cancer. 2012;131(11):2604-11.

15. Luo M, Song H, Liu G, Lin Y, Luo L, Zhou X, Chen B. Comparison of DWI and (18)F-FDG PET/ $\mathrm{CT}$ for assessing preoperative N-staging in gastric cancer: evidence from a meta-analysis. Oncotarget. 2017;8(48):84473-88.

16. Wu Z, Zhao J, Gao P, Song Y, Sun J, Chen X, et al. Prognostic value of pretreatment standardized uptake value of F-18-fluorodeoxyglucose PET in patients with gastric cancer: a meta-analysis. BMC Cancer. 2017;17(1):275.

17. Li P, Liu Q, Wang C, Wang T, Liu J, Huang G, Song S. Fluorine-18-fluorodeoxyglucose positron emission tomography to evaluate recurrent gastric cancer after surgical resection: a systematic review and meta-analysis. Ann Nucl Med. 2016;30(3):179-87.

18. Zou H, Zhao Y. 18FDG PET-CT for detecting gastric cancer recurrence after surgical resection: a metaanalysis. Surg Oncol. 2013;22(3):162-6.

19. Cui JX, Li T, Xi HQ, Wei B, Chen L. [Evaluation of (18)F-FDG PET/CT in preoperative staging of gastric cancer: a meta-analysis]. Zhonghua Wei Chang Wai Ke Za Zhi. 2013;16(5):418-24.

20. Wu LM, Hu JN, Hua J, Gu HY, Zhu J, Xu JR. 18 F-fluorodeoxyglucose positron emission tomography to evaluate recurrent gastric cancer: a systematic review and meta-analysis. J Gastroenterol Hepatol. 2012;27(3):472-80.

21. Seevaratnam R, Cardoso R, McGregor C, Lourenco L, Mahar A, Sutradhar R, et al. How useful is preoperative imaging for tumor, node, metastasis (TNM) staging of gastric cancer? A meta-analysis. Gastric Cancer. 2011;15(Suppl 1):S3-18.

22. Sadeghi R, Harsini S, Qodsi Rad MA, Dabbagh VR, Treglia G. Prognostic significance of fluorine-18 fluorodeoxyglucose positron emission tomography in anal squamous cell carcinoma: a systematic review and a meta-analysis. Contrast Media Mol Imaging. 2018;2018:9760492.

23. Albertsson P, Alverbratt C, Liljegren A, Björkander E, Strandell A, Samuelsson O, et al. Positron emission tomography and computed tomographic (PET/ $\mathrm{CT}$ ) imaging for radiation therapy planning in anal cancer: a systematic review and meta-analysis. Crit Rev Oncol Hematol. 2018;126:6-12.

24. Mahmud A, Poon R, Jonker D. PET imaging in anal canal cancer: a systematic review and meta-analysis. Br J Radiol. 2017;90(1080):20170370.

25. Jones M, Hruby G, Solomon M, Rutherford N, Martin J. The role of FDG-PET in the initial staging and response assessment of anal cancer: a systematic review and meta-analysis. Ann Surg Oncol. 2015;22(11):3574-81.

26. Caldarella C, Annunziata S, Treglia G, Sadeghi R, Ayati N, Giovanella L. Diagnostic perfor- 
mance of positron emission tomography/computed tomography using fluorine-18 fluorodeoxyglucose in detecting locoregional nodal involvement in patients with anal canal cancer: a systematic review and meta-analysis. ScientificWorldJournal. 2014;2014:196068.

27. Kim SJ, Lee SW. Performance of F-18 FDG PET/ $\mathrm{CT}$ for predicting malignant potential of gastrointestinal stromal tumors: a systematic review and meta-analysis. J Gastroenterol Hepatol. 2018;33(3):576-82.

28. Hassanzadeh-Rad A, Yousefifard M, Katal S, Asady H, Fard-Esfahani A, Moghadas Jafari A, et al. The value of (18) F-fluorodeoxyglucose positron emission tomography for prediction of treatment response in gastrointestinal stromal tumors: a systematic review and meta-analysis. J Gastroenterol Hepatol. 2016;31(5):929-35.

29. Liao X, Wei J, Li Y, Zhong J, Liu Z, Liao S, et al. 18F-FDG PET with or without CT in the diagnosis of extrahepatic metastases or local residual/recurrent hepatocellular carcinoma. Medicine (Baltimore). 2018;97(34):e11970.

30. Hu JH, Tang JH, Lin CH, Chu YY, Liu NJ. Preoperative staging of cholangiocarcinoma and biliary carcinoma using $18 \mathrm{~F}$-fluorodeoxyglucose positron emission tomography: a meta-analysis. J Investig Med. 2018;66(1):52-61.

31. Sun DW, An L, Wei F, Mu L, Shi XJ, Wang CL, et al. Prognostic significance of parameters from pretreatment (18)F-FDG PET in hepatocellular carcinoma: a meta-analysis. Abdom Radiol. 2016;41(1):33-41.

32. Annunziata S, Pizzuto DA, Caldarella C, Galiandro F, Sadeghi R, Treglia G. Diagnostic accuracy of fluorine-18-fluorodeoxyglucose positron emission tomography in gallbladder cancer: a meta-analysis. World J Gastroenterol. 2015;21(40):11481-8.

33. Zhang H, Zhu J, Ke F, Weng M, Wu X, Li M, et al. Radiological imaging for assessing the respectability of hilar cholangiocarcinoma: a systematic review and meta-analysis. Biomed Res Int. 2015;2015:497942.

34. Bertagna F, Bertoli M, Bosio G, Biasiotto G, Sadeghi $\mathrm{R}$, Giubbini R, et al. Diagnostic role of radiolabelled choline PET or PET/CT in hepatocellular carcinoma: a systematic review and meta-analysis. Hepatol Int. 2014;8(4):493-500.

35. Chou R, Cuevas C, Fu R, Devine B, Wasson N, Ginsburg A, et al. Imaging techniques for the diagnosis and staging of hepatocellular carcinoma [Internet]. Rockville, MD: Agency for Healthcare Research and Quality (US); 2014. http://www.ncbi. nlm.nih.gov/books/NBK254191/.

36. Annunziata S, Caldarella C, Pizzuto DA, Galiandro F, Sadeghi R, Giovanella L, et al. Diagnostic accuracy of fluorine-18-fluorodeoxyglucose positron emission tomography in the evaluation of the pri- mary tumor in patients with cholangiocarcinoma: a meta-analysis. Biomed Res Int. 2014;2014:247693.

37. Lin CY, Chen JH, Liang JA, Lin CC, Jeng LB, Kao CH. 18F-FDG PET or PET/CT for detecting extrahepatic metastases or recurrent hepatocellular carcinoma: a systematic review and meta-analysis. Eur J Radiol. 2012;81(9):2417-22.

38. Choi SH, Kim SY, Park SH, Kim KW, Lee JY, Lee $\mathrm{SS}$, et al. Diagnostic performance of CT, gadoxetate disodium-enhanced MRI, and PET/CT for the diagnosis of colorectal liver metastasis: systematic review and meta-analysis. J Magn Reason Imaging. 2018;47(5):1237-50.

39. Samim M, Molenaar IQ, Seesing MFJ, van Rossum PSN, van den Bosch MAAJ, Ruers TJM, et al. The diagnostic performance of (18)F-FDG PET/ CT, CT and MRI in the treatment evaluation of ablation therapy for colorectal liver metastases: a systematic review and meta-analysis. Surg Oncol. 2017;26(1):37-45.

40. Maffione AM, Lopci E, Bluemel C, Giammarile F, Herrmann K, Rubello D. Diagnostic accuracy and impact on management of (18)F-FDG PET and PET/ $\mathrm{CT}$ in colorectal liver metastasis: a meta-analysis and systematic review. Eur J Nucl Med Mol Imaging. 2015;42(1):152-63.

41. Deng J, Tang J, Shen N. Meta-analysis of diagnosis of liver metastatic cancers: comparison of (18) FDG PET-CT and gadolinium-enhanced MRI. J Med Imaging Radiat Oncol. 2014;58(5):532-7.

42. Zheng JH, Chang ZH, Han CB, Ma JT, Liu ZY, $\mathrm{Lu} \mathrm{ZM}$, et al. Detection of residual tumor following radiofrequency ablation of liver metastases using 18F-FDG PET/PET-CT: a systematic review and meta-analysis. Nucl Med Commun. 2014;35(4):339-46.

43. Poulou LS, Ziakas PD, Ziogas DC, Doxani C, Xyla V, Vakrinos G, et al. FDG-PET for detecting local tumor recurrence of ablated liver metastases: a diagnostic meta-analysis. Biomarkers. 2012;17(6):532-8.

44. van Kessel CS, Buckens CF, van den Bosch MA, van Leeuwen MS, van Hillegersberg R, Verkooijen HM. Preoperative imaging of colorectal liver metastases after neoadjuvant chemotherapy: a metaanalysis. Ann Surg Oncol. 2012;19(9):2805-13.

45. Daamen LA, Groot VP, Goense L, Wessels FJ, Borel Rinkes IH, Intven MPW, et al. The diagnostic performance of CT versus FDG PET-CT for the detection of recurrent pancreatic cancer: a systematic review and meta-analysis. Eur J Radiol. 2018;106:128-36.

46. Wang L, Dong P, Wang WG, Tian BL. Positron emission tomography modalities prevent futile radical resection of pancreatic cancer: a meta-analysis. Int J Surg. 2017;46:119-25. 
47. Zhu D, Wang L, Zhang H, Chen J, Wang Y, Byanju S, Liao M. Prognostic value of 18F-FDG-PET/CT parameters in patients with pancreatic carcinoma: a systematic review and meta-analysis. Medicine. 2017;96(33):e7813.

48. Toft J, Hadden WJ, Laurence JM, Lam V, Yuen L, Janssen A, et al. Imaging modalities in the diagnosis of pancreatic adenocarcinoma: a systematic review and meta-analysis of sensitivity, specificity and diagnostic accuracy. Eur J Radiol. 2017;92:17-23.

49. Best LM, Rawji V, Pereira SP, Davidson BR, Gurusamy KS. Imaging modalities for characterising focal pancreatic lesions. Cochrane Database Syst Rev. 2017;4:CD010213.

50. Rijkers AP, Valkema R, Duivenvoorden HJ, van Eijck CH. Usefulness of F-18-fluorodeoxyglucose positron emission tomography to confirm suspected pancreatic cancer: a meta-analysis. Eur J Surg Oncol. 2014;40(7):794-804.

51. Wang Z, Chen JQ, Liu JL, Qin XG, Huang Y. FDGPET in diagnosis, staging and prognosis of pancreatic carcinoma: a meta-analysis. World J Gastroenterol. 2013;19(29):4808-17.

52. Wu LM, Hu JN, Hua J, Liu MJ, Chen J, Xu JR. Diagnostic value of diffusion-weighted magnetic resonance imaging compared with fluorodeoxyglucose positron emission tomography/computed tomography for pancreatic malignancy: a meta-analysis using a hierarchical regression model. J Gastroenterol Hepatol. 2012;27(6):1027-35.

53. Ruan J, Zhang Y, Ren H. Meta-analysis of PET/CT detect lymph nodes metastases of cervical cancer. Open Med. 2018;13:436-42.

54. Han S, Kim H, Kim YJ, Suh CH, Woo S. Prognostic value of volume-based metabolic parameters of (18)F-FDG PET/CT in uterine cervical cancer: a systematic review and meta-analysis. AJR Am J Roentgenol. 2018;211(5):1112-21.

55. Zhou Z, Liu X, Hu K, Zhang F. The clinical value of $\mathrm{PET}$ and PET/CT in the diagnosis and management of suspected cervical cancer recurrence. Nucl Med Commun. 2018;39(2):97-102.

56. Liu B, Gao S, Li S. A comprehensive comparison of CT, MRI, positron emission tomography or positron emission tomography/CT, and diffusion weighted imaging-MRI for detecting the lymph nodes metastases in patients with cervical cancer: a meta-analysis based on 67 studies. Gynecol Obstet Invest. 2017;82(3):209-22.

57. Sarker A, Im HJ, Cheon GJ, Chung HH, Kang KW, Chung JK, et al. Prognostic implications of the SUVmax of primary tumors and metastatic lymph node measured by 18F-FDG PET in patients with uterine cervical cancer: a meta-analysis. Clin Nucl Med. 2016;41(1):34-40.

58. Xiao Y, Wei J, Zhang Y, Xiong W. Positron emission tomography alone, positron emission tomography- computed tomography and computed tomography in diagnosing recurrent cervical carcinoma: a systematic review and meta-analysis. Arch Med Sci. 2014;10(2):222-31.

59. Ding XP, Feng L, Ma L. Diagnosis of recurrent uterine cervical cancer: PET versus PET/CT: a systematic review and meta-analysis. Arch Gynecol Obstet. 2014;290(4):741-7.

60. Meads C, Davenport C, Małysiak S, Kowalska M, Zapalska A, Guest P, et al. Evaluating PET-CT in the detection and management of recurrent cervical cancer: systematic reviews of diagnostic accuracy and subjective elicitation. BJOG. 2014;121(4):398-407.

61. Chu Y, Zheng A, Wang F, Lin W, Yang X, Han L, et al. Diagnostic value of 18F-FDG-PET or PET-CT in recurrent cervical cancer: a systematic review and meta-analysis. Nucl Med Commun. 2014;35(2):144-50.

62. Zhao Q, Feng Y, Mao X, Qie M. Prognostic value of fluorine-18-fluorodeoxyglucose positron emission tomography or PET-computed tomography in cervical cancer: a meta-analysis. Int J Gynecol Cancer. 2013;23(7):1184-90.

63. Meads C, Auguste P, Davenport C, Małysiak S, Sundar S, Kowalska M, et al. Positron emission tomography/computerised tomography imaging in detecting and managing recurrent cervical cancer: systematic review of evidence, elicitation of subjective probabilities and economic modelling. Health Technol Assess. 2013;17(12):1-323.

64. Gong Y, Wang Q, Dong L, Jia Y, Hua C, Mi F, et al. Different imaging techniques for the detection of pelvic lymph nodes metastasis from gynecological malignancies: a systematic review and metaanalysis. Oncotarget. 2017;8(8):14107-25.

65. Bollineni VR, Ytre-Hauge S, Bollineni-Balabay O, Salvesen HB, Haldorsen IS. High diagnostic value of 18F-FDG PET/CT in endometrial cancer: systematic review and meta-analysis of the literature. $\mathrm{J}$ Nucl Med. 2016;57(6):879-85.

66. Pan Y, Yao Y, Ma Y. Standardized uptake value on F-FDG PET/CT as a prognostic factor for survival of women with malignant uterine tumors: a metaanalysis. Gynecol Obstet Investig. 2016;81:124-31.

67. Ghooshkhanei H, Treglia G, Sabouri G, Davoodi R, Sadeghi R. Risk stratification and prognosis determination using (18)F-FDG PET imaging in endometrial cancer patients: a systematic review and meta-analysis. Gynecol Oncol. 2014;132(3):669-76.

68. Kakhki VR, Shahriari S, Treglia G, Hasanzadeh M, Zakavi SR, Yousefi Z, et al. Diagnostic performance of fluorine 18 fluorodeoxyglucose positron emission tomography imaging for detection of primary lesion and staging of endometrial cancer patients: systematic review and meta-analysis of the literature. Int $\mathbf{J}$ Gynecol Cancer. 2013;23(9):1536-43.

69. Sadeghi R, Zakavi SR, Hasanzadeh M, Treglia G, Giovanella L, Kadkhodayan S. Diagnostic perfor- 
mance of fluorine-18-fluorodeoxyglucose positron emission tomography imaging in uterine sarcomas: systematic review and meta-analysis of the literature. Int J Gynecol Cancer. 2013;23(8):1349-56.

70. Kadkhodayan S, Shahriari S, Treglia G, Yousefi Z, Sadeghi R. Accuracy of 18-F-FDG PET imaging in the follow up of endometrial cancer patients: systematic review and meta-analysis of the literature. Gynecol Oncol. 2013;128(2):397-404.

71. Chang MC, Chen JH, Liang JA, Yang KT, Cheng KY, Kao CH. 18F-FDG PET or PET/CT for detection of metastatic lymph nodes in patients with endometrial cancer: a systematic review and meta-analysis. Eur J Radiol. 2012;81(11):3511-7.

72. Han S, Woo S, Suh CH, Lee JJ. Performance of pretreatment ${ }^{18} \mathrm{~F}$-fluorodeoxyglucose positron emission tomography/computed tomography for detecting metastasis in ovarian cancer: a systematic review and meta-analysis. J Gynecol Oncol. 2018;29(6):e98.

73. Han S, Kim H, Kim YJ, Suh CH, Woo S. Prognostic value of volume-based metabolic parameters of (18)F-FDG PET/CT in ovarian cancer: a systematic review and meta-analysis. Ann Nucl Med. 2018;32(10):669-77.

74. Suppiah S, Chang WL, Hassan HA, Kaewput C, Asri AAA, Saad FFA, et al. Systematic review on the accuracy of positron emission tomography/computed tomography and positron emission tomography/magnetic resonance imaging in the management of ovarian cancer: is functional information really needed? World J Nucl Med. 2017;16(3):176-85.

75. Xu B, Ma J, Jiang G, Wang Y, Ma Q. Diagnostic value of positron emission tomography (PET) and $\mathrm{PET} /$ computed tomography in recurrent/metastatic ovarian cancer: a meta-analysis. J Obstet Gynaecol Res. 2017;43(2):378-86.

76. Limei Z, Yong C, Yan X, Shuai T, Jiangyan X, Zhiqing L. Accuracy of positron emission tomography/computed tomography in the diagnosis and restaging for recurrent ovarian cancer: a metaanalysis. Int J Gynecol Cancer. 2013;23(4):598-607.

77. Yuan Y, Gu ZX, Tao XF, Liu SY. Computer tomography, magnetic resonance imaging, and positron emission tomography or positron emission tomography/computer tomography for detection of metastatic lymph nodes in patients with ovarian cancer: a meta-analysis. Eur J Radiol. 2012;81(5):1002-6.

78. Kim SJ, Lee SW. Diagnostic accuracy of (18)F-FDG PET/CT for detection of peritoneal carcinomatosis; a systematic review and meta-analysis. Br J Radiol. 2018;91(1081):20170519.

79. Li J, Yan R, Lei J, Jiang C. Comparison of PET with PET/CT in detecting peritoneal carcinomatosis: a meta-analysis. Abdom Imaging. 2015;40(7):2660-6.

80. Chang MC, Chen JH, Liang JA, Huang WS, Cheng $\mathrm{KY}$, Kao CH. PET or PET/CT for detection of peritoneal carcinomatosis: a meta-analysis. Clin Nucl Med. 2013;38(8):623-9.
81. Zheng M, Xie D, Pan C, Xu Y, Yu W. Diagnostic value of $18 \mathrm{~F}-\mathrm{FDG}$ PET/MRI in recurrent pelvis malignancies of female patients: a systematic review and meta-analysis. Nucl Med Commun. 2018;39(6):479-85.

82. Nie J, Zhang J, Gao J, Guo L, Zhou H, Hu Y, et al. Diagnostic role of 18F-FDG PET/MRI in patients with gynecological malignancies of the pelvis: a systematic review and meta-analysis. PLoS One. 2017;12(5):e0175401.

83. Evangelista L, Guttilla A, Zattoni F, Muzzio PC, Zattoni F. Utility of choline positron emission tomography/computed tomography for lymph node involvement identification in intermediate- to highrisk prostate cancer: a systematic literature review and meta-analysis. Eur Urol. 2013;63(6):1040-8.

84. Evangelista L, Zattoni F, Guttilla A, Saladini G, Zattoni F, Colletti PM, et al. Choline PET or PET/ $\mathrm{CT}$ and biochemical relapse of prostate cancer: a systematic review and meta-analysis. Clin Nucl Med. 2013;38(5):305-14.

85. Evangelista L, Zattoni F, Karnes RJ, Novara G, Lowe V. Radiolabeled choline PET/CT before salvage lymphadenectomy dissection: a systematic review and meta-analysis. Nucl Med Commun. 2016;37(12):1223-31.

86. Fanti S, Minozzi S, Castellucci P, Balduzzi S, Herrmann K, Krause BJ, et al. PET/CT with (11) C-choline for evaluation of prostate cancer patients with biochemical recurrence: meta-analysis and critical review of available data. Eur J Nucl Med Mol Imaging. 2016;43(1):55-69.

87. Umbehr MH, Muntener M, Hany $\mathrm{T}$, Sulser $\mathrm{T}$, Bachmann LM. The role of 11C-choline and 18F-fluorocholine positron emission tomography (PET) and PET/CT in prostate cancer: a systematic review and meta-analysis. Eur Urol. 2013;64(1):106-17.

88. Treglia G, Ceriani L, Sadeghi R, Giovacchini G, Giovanella L. Relationship between prostatespecific antigen kinetics and detection rate of radiolabelled choline PET/CT in restaging prostate cancer patients: a meta-analysis. Clin Chem Lab Med. 2014;52(5):725-33.

89. Wei J, Zhu H, Liao X. Trigger pSA predicting recurrence from positive choline PET/CT with prostate cancer after initial treatment. Oncotarget. 2018;9(18):14630-41.

90. Guo Y, Wang L, Hu J, Feng D, Xu L. Diagnostic performance of choline PET/CT for the detection of bone metastasis in prostate cancer: a systematic review and meta-analysis. PLoS One. 2018;13(9):e0203400.

91. Shen G, Deng H, Hu S, Jia Z. Comparison of choline-PET/CT, MRI, SPECT, and bone scintigraphy in the diagnosis of bone metastases in patients with prostate cancer: a meta-analysis. Skelet Radiol. 2014;43(11):1503-13. 
92. Liu J, Chen Z, Wang T, Liu L, Zhao L, Guo G, et al. Influence of four radiotracers in PET/CT on diagnostic accuracy for prostate cancer: a bivariate random-effects meta-analysis. Cell Physiol Biochem. 2016;39(2):467-80.

93. Beheshti M, Giorgio T, Rasoul ZS, Werner L, Ali GR, Reza DK, et al. Application of C-11acetate positron-emission tomography (PET) imaging in prostate cancer: systematic review and meta-analysis of the literature. BJU Int. 2013;112(8):1062-72.

94. Ouyang Q, Duan Z, Lei J, Jiao G. Comparison of meta-analyses among elastosonography (ES) and positron emission tomography/computed tomography (PET/CT) imaging techniques in the application of prostate cancer diagnosis. Tumour Biol. 2016;37(3):2999-3007.

95. von Eyben FE, Kairemo K. Acquisition with (11) C-choline and (18)F-fluorocholine PET/CT for patients with biochemical recurrence of prostate cancer: a systematic review and meta-analysis. Ann Nucl Med. 2016;30(6):385-92.

96. Corfield J, Perera M, Bolton D, Lawrentschuk N. (68)Ga-prostate specific membrane antigen (PSMA) positron emission tomography (PET) for primary staging of high-risk prostate cancer: a systematic review. World J Urol. 2018;36(4):519-27.

97. Hope TA, Goodman JZ, Allen IE, Calais J, Fendler WP, Carroll PR. Metaanalysis of (68)Ga-PSMA-11 PET accuracy for the detection of prostate cancer validated by histopathology. J Nucl Med. 2019;60(6):786-93.

98. Han S, Woo S, Kim YJ, Suh CH. Impact of (68) Ga-PSMA PET on the management of patients with prostate cancer: a systematic review and metaanalysis. Eur Urol. 2018;74(2):179-90.

99. Kim SJ, Lee SW, Ha HK. Diagnostic performance of radiolabeled prostate-specific membrane antigen positron emission tomography/computed tomography for primary lymph node staging in newly diagnosed intermediate to high-risk prostate cancer patients: a systematic review and meta-analysis. Urol Int. 2019;102(1):27-36.

100. Perera M, Papa N, Christidis D, Wetherell D, Hofman MS, Murphy DG, et al. Sensitivity, specificity, and predictors of positive (68)Ga-prostate-specific membrane antigen positron emission tomography in advanced prostate cancer: a systematic review and meta-analysis. Eur Urol. 2016;70(6):926-37.

101. von Eyben FE, Picchio M, von Eyben R, Rhee H, Bauman G. (68)Ga-labeled prostate-specific membrane antigen ligand positron emission tomography/ computed tomography for prostate cancer: a systematic review and meta-analysis. Eur Urol Focus. 2018;4(5):686-93.
102. Pereira Mestre R, Treglia G, Ferrari M, Pascale M, Mazzara C, Azinwi NC, et al. Correlation between PSA kinetics and PSMA-PET in prostate cancer restaging: a meta-analysis. Eur J Clin Investig. 2019;49(3):e13063.

103. Crozier J, Papa N, Perera M, Ngo B, Bolton D, Sengupta $\mathrm{S}$, et al. Comparative sensitivity and specificity of imaging modalities in staging bladder cancer prior to radical cystectomy: a systematic review and meta-analysis. World $\mathrm{J}$ Urol. 2019;37(4):667-90.

104. Ha HK, Koo PJ, Kim SJ. Diagnostic accuracy of F-18 FDG PET/CT for preoperative lymph node staging in newly diagnosed bladder cancer patients: a systematic review and meta-analysis. Oncology. 2018;95(1):31-8.

105. Lu YY, Chen JH, Liang JA, Wang HY, Lin CC, Lin WY, et al. Clinical value of FDG PET or PET/CT in urinary bladder cancer: a systemic review and metaanalysis. Eur J Radiol. 2012;81(9):2411-6.

106. Soubra A, Hayward D, Dahm P, Goldfarb R, Froehlich J, Jha G, et al. The diagnostic accuracy of $18 \mathrm{~F}$-fluorodeoxyglucose positron emission tomography and computed tomography in staging bladder cancer: a single-institution study and a systematic review with meta-analysis. World J Urol. 2016;34(9):1229-37.

107. Wang N, Jiang P, Lu Y. Is fluorine-18 fluorodeoxyglucose positron emission tomography useful for detecting bladder lesions? A meta-analysis of the literature. Urol Int. 2014;92(2):143-9.

108. Zhang H, Xing W, Kang Q, Chen C, Wang L, Lu J. Diagnostic value of [18F] FDG-PET and PET/CT in urinary bladder cancer: a meta-analysis. Tumour Biol. 2015;36(5):3209-14.

109. Kim SJ, Koo PJ, Pak K, Kim IJ, Kim K. Diagnostic accuracy of C-11 choline and C-11 acetate for lymph node staging in patients with bladder cancer: a systematic review and meta-analysis. World $\mathrm{J}$ Urol. 2018;36(3):331-40.

110. Ma H, Shen G, Liu B, Yang Y, Ren P, Kuang A. Diagnostic performance of $18 \mathrm{~F}-\mathrm{FDG}$ PET or $\mathrm{PET} / \mathrm{CT}$ in restaging renal cell carcinoma: a systematic review and meta-analysis. Nucl Med Commun. 2017;38(2):156-63.

111. Wang HY, Ding HJ, Chen JH, Chao CH, Lu YY, Lin WY, et al. Meta-analysis of the diagnostic performance of [18F]FDG-PET and PET/CT in renal cell carcinoma. Cancer Imaging. 2012;12:464-74.

112. Zhao JY, Ma XL, Li YY, Zhang BL, Li MM, Ma $\mathrm{XL}$, et al. Diagnostic accuracy of 18F-FDG-PET in patients with testicular cancer: a meta-analysis. Asian Pac J Cancer Prev. 2014;15(8):3525-31.

113. Treglia G, Sadeghi R, Annunziata S, Caldarella C, Bertagna F, Giovanella L. Diagnostic performance 
of fluorine-18-fluorodeoxyglucose positron emission tomography in the postchemotherapy management of patients with seminoma: systematic review and meta-analysis. Biomed Res Int. 2014;2014:852681.

114. Sadeghi R, Gholami H, Zakavi SR, Kakhki VR, Horenblas S. Accuracy of 18F-FDG PET/CT for diagnosing inguinal lymph node involvement in penile squamous cell carcinoma: systematic review and meta-analysis of the literature. Clin Nucl Med. 2012;37(5):436-41.

115. Ren J, Yuan L, Wen G, Yang J. The value of anti1-amino-3-18F-fluorocyclobutane-1-carboxylic acid PET/CT in the diagnosis of recurrent prostate carcinoma: a meta-analysis. Acta Radiol. 2016;57(4):487-93.

116. Sathianathen NJ, Butaney M, Konety BR. The utility of PET-based imaging for prostate cancer biochemical recurrence: a systematic review and metaanalysis. World J Urol. 2019;37(7):1239-49.

117. Bertagna F, Sadeghi R, Giovanella L, Treglia G. Incidental uptake of $18 \mathrm{~F}$-fluorodeoxyglucose in the prostate gland. Systematic review and metaanalysis on prevalence and risk of malignancy. Nuklearmedizin. 2014;53(6):249-58.

Open Access This chapter is licensed under the terms of the Creative Commons Attribution 4.0 International License (http://creativecommons.org/licenses/by/4.0/), which permits use, sharing, adaptation, distribution and reproduction in any medium or format, as long as you give appropriate credit to the original author(s) and the source, provide a link to the Creative Commons license and indicate if changes were made.

The images or other third party material in this chapter are included in the chapter's Creative Commons license, unless indicated otherwise in a credit line to the material. If material is not included in the chapter's Creative Commons license and your intended use is not permitted by statutory regulation or exceeds the permitted use, you will need to obtain permission directly from the copyright holder. 